\title{
Optimising Cutinase Enzyme Recovery in Thermo-Induced Phase Separation of LS54/ DX ATPS by Enhanced Volume Exclusion Effect
}

\author{
(Pengoptimuman Perolehan Enzim Kutinase pada Fasa Pemisahan Teraruh-suhu S2FA LS54/DX dengan Meningkatkan \\ Kesan Penyingkiran Isipadu) \\ Fariza Akmal Abdul Mutalib \\ Department of Chemical and Process Engineering, Faculty of Engineering \& Built Environment \\ Universiti Kebangsaan Malaysia (UKM), 43600, Bangi, Selangor, Malaysia \\ Jamaliah Md Jahim* \\ Department of Chemical and Process Engineering, Faculty of Engineering \& Built Environment \\ Research Centre for Sustainable Process Technology, Faculty of Engineering \& Built Environment \\ Universiti Kebangsaan Malaysia (UKM), 43600, Bangi, Selangor, Malaysia \\ Abdul Wahab Mohammad \\ Department of Chemical and Process Engineering, Faculty of Engineering \& Built Environment \\ Research Centre for Sustainable Process Technology, Faculty of Engineering \& Built Environment \\ Universiti Kebangsaan Malaysia (UKM), 43600, Bangi, Selangor, Malaysia \\ Qatar Energy and Environment Research Instititue, Hamad bin Khalifa University (HBKU), Qatar Foundation, Doha, Qatar \\ Farah Diba Abu Bakar \\ Centre of Bioscience \& Biotechnology Studies, Faculty of Science \& Technology \\ Universiti Kebangsaan Malaysia (UKM), 43600, Bangi, Selangor, Malaysia
}

\begin{abstract}
Low recovery of cutinase enzyme in water-enriched phase after thermo-induced separation stage of LS54/Dx aqueous twophase system was improved by enhanced volume exclusion effect in the polymer-water extraction system. It was done by increased the polymer concentration in the polymer-water system. After primary phase separation, more LS54 (polymer) which is the system's component itself were added into polymer-enriched phase and mixed thoroughly before thermo-induced separation step proceeded. The compositions of LS54 added into the polymer-enriched phase were $0.25,0.5$ and $0.75 \mathrm{~g}$ $\mathrm{LS54} / \mathrm{g}$ top phase. The thermo-induced phase separation was carried out at $37^{\circ} \mathrm{C}$. It was found that cutinase recovery in water-enriched phase was increased up to 5-13\% with the increment of polymer concentration in the system as compared to a system without polymer addition. The optimum concentration obtained for the polymer added was $0.5 \mathrm{~g}$ LS54/g top phase whereby it attained $82 \%$ recovery of cutinase enzyme in water-enriched phase after thermoseparation step. Although the increment of enzyme recovery was not exceptionally high as compared to another method such as adding ligand, an affinity tag or neutral salt, still this method is applicable because of its more straightforward work, polymer recycle capability, and enzyme recovery in water phase would definitely give benefit to further downstream processing.
\end{abstract}

Keywords: Aqueous two phase system (ATPS); thermoseparation; enzyme recovery; volume-exclusion effect

ABSTRAK

Perolehan rendah enzim cutinase dalam fasa diperkaya air selepas peringkat pemisahan teraruh suhu sistem dua fasa berakueus LS54/Dx ditambahbaik dengan meningkatkan kesan penyingkiran isipadu dalam sistem pengekstrakan polimerair. Ia dilakukan dengan meningkatkan kepekatan polimer dalam sistem pengekstrakan tersebut. Selepas pemisahan fasa utama, lebih banyak LS54 (polimer) iaitu komponen sistem ini sendiri, telah ditambah ke dalam fasa diperkaya polimer dan dicampur dengan baik sebelum langkah pemisahan teraruh suhu diteruskan. Komposisi LS54 yang ditambahkan ke dalam

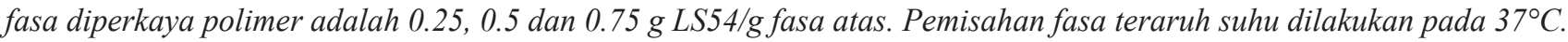
Didapati perolehan cutinase dalam fasa diperkaya air meningkat sehingga 5-13\% dengan peningkatan kepekatan polimer dalam sistem berbanding dengan sistem tanpa penambahan polimer. Kepekatan optimum yang diperolehi bagi penambahan

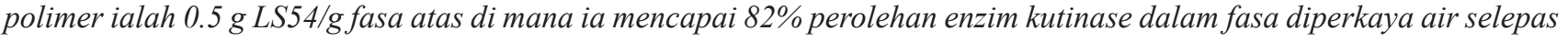
langkah pemisahan teraruh suhu. Walaupun peningkatan perolehan enzim tidak begitu tinggi berbanding dengan kaedah lain seperti penambahan ligan, tag affinity atau garam neutral, namun kaedah ini boleh diguna pakai kerana kerjanya yang lebih mudah, berkeupayaan kitar semula polimer, dan perolehan enzim dalam fasa air pasti memberi manfaat untuk pemprosesan hiliran seterusnya.

Kata kunci: Sistem Dua Fasa Berakueus (S2FA); pemisahan teraruh suhu; perolehan enzim; kesan penyingkiran isipadu 
INTRODUCTION

Application of thermo-induced polymer in aqueous twophase system (ATPS) development has earned more attention recently. Unlike the other type of ATPS, the used of the thermo-responsive polymer has made the system capable of extracting product from the polymer-rich phase directly by changing the environment condition which is temperature, and the product-free polymer phase can be recycled for back extraction. Additionally, recovery of target biomolecules/ bioproducts in water-rich phase would undoubtedly give benefits to the following steps in downstream processing.

ATPS has been one of the preferred methods in extraction and purification of biomolecules because of its simplicity, selectivity and relatively a low-cost method (Espitia-Saloma et al. 2014; Goja et al. 2013; Leong et al. 2015). The mild condition provided by ATPS has been another factor that makes it keep progressing in bioseparation area. ATPS had been applied not only for the recovery of proteins and enzymes but also had been used for extraction of high-end bioproducts such as recombinant therapeutic proteins, monoclonal antibody-based products $(\mathrm{mAb})$ and nucleic acid-based medicinal products (Rosa et al. 2010).

In order to achieve higher yield, several strategies have been applied in ATPS method. It was either manipulation of system's parameter (for example type, composition \& polymer size, $\mathrm{pH}$ ), altering the type of ions in the system, adding additional salt, or exploiting the hydrophobic groups) (Asenjo et al. 2012). Yet, most of the strategies were generally used in primary-phase separation. Only several studies had discussed the recovery of proteins/enzymes in a thermo-induced stage. For example, Jo"nsson and Johansson (2003) had modified a hydrophobically thermo-responsive polymer (HM-EO) to a cationic polymer in order to manipulate electronic interaction between protein and the polymer in water/HM-EO system by changing $\mathrm{pH}$, micellar net-charge and salt addition.

The separation of biomolecules in water/thermoresponsive polymer system driven by entropic effect is a well-established concept (Johansson et al. 1998). As the temperature increased, the entropy energy of polymer rich phase would be increased. This situation would drive biomolecules partition exclusively into less chaotic, waterenriched phase. This excluded volume concept was similar to the aqueous micellar system. In addition, volume fraction of micelles in micelle-rich phase is vital determinant to the magnitude of the excluded-volume interactions that are driving the partitioning of biomolecules into less-micelle phase (van Roosmalen et al. 2004). With that information, this study was conducted by increasing volume fraction of polymer in polymer-enriched phase, as an attempt to optimise the recovery of cutinase in water-enrich phase. It was done by adding more polymer into polymer-enriched phase at several concentrations before the thermoseparation phase.
METHODOLOGY

MATERIALS

Dehypon ${ }^{\circledR L S} 54$ (LS54), an industrial grade low-foaming surfactant was purchased from Emery Oleochemicals Group, Malaysia. Meanwhile, K4484®Dextrin, a tapioca-based dextrin, was supplied by N-Starch Sdn. Bhd. (Malaysia). The industrial cutinase enzyme named Novozym 51032 $₫$, was purchased from Novozyme (Denmark) and used as a model enzyme in this study. All acids and salt reagents were Analar grade and purchased from Sigma (USA) and Merck (Germanay). p-nitrophenyl laurate (pNPL) and p-nitrophenol $(\mathrm{pNp})$ were obtained from Tokyo Chemical Industry Co. Ltd (Japan) and Fluka (Switzerland), respectively.

\section{PRIMARY PHASE SEPARATION}

30 gram of ATPS with $22 \% \mathrm{LS} 54 / 12.5 \% \mathrm{Dx} / 0.1 \mathrm{M} \mathrm{NaCl}$ as total composition were prepared in separating funnel by adding Dehypon LS54 (without dilution) with Dx (30\% w/w stock solution) and $\mathrm{NaCl}(1.0 \mathrm{M})$ at certain amounts. Meanwhile, $\mathrm{pH}$ of the system was adjusted to 8.0 with potassium phosphate buffer. The system mixtures were inverted several times for mixing. After that, it was incubated in waterbath for a complete separation at the experiment temperature which is $30^{\circ} \mathrm{C}$. After a complete two-phase system was observed, the top and bottom phase was separated carefully.

THERMO-INDUCED SEPARATION

The top LS54-enriched phase from the primary stage separation was withdrawn and separated from the bottom dextrin-enriched phase. In order to determine the optimum composition of polymer added for better enzyme recovery in the water phase, three test tubes $(15 \mathrm{ml})$ were prepared wherein each tube was filled with $4 \mathrm{~g}$ of LS54-enriched phase. Then, each tube was added with an undiluted LS54 solution at a different volume of $1 \mathrm{~g}, 2 \mathrm{~g}$ and $3 \mathrm{~g}$, respectively. Polymer volume of more than $3 \mathrm{~g}$ was not tested due to prevent high viscosity system as it would difficult in handling. The mixture was then centrifuged at $6000 \mathrm{rpm}$ and incubated at $37^{\circ} \mathrm{C}$ until a new two-phase system was formed. The top phase enriched with LS54, while the bottom phase consists of water. Summary of the experiment conducted is depicted in Figure 1.

\section{ANALYSIS}

Cutinase activity was measured according to work done by Kumar et al. (2005). A reaction mixture composed of $96.5 \mu \mathrm{l}$ potassium phosphate buffer, $2.5 \mu 1$ of p-nitrophenyl laurate (pNPL) and $1.0 \mu 1$ sample were prepared and allowed to react for $10 \mathrm{~min}$. The absorbance was measured at $405 \mathrm{~nm}$ by using VersaMax microplate reader (USA). A system without protein/ enzyme was prepared as a blank. One unit activity (U) of cutinase is defined as $1 \mu \mathrm{mol}$ p-nitrophenol (pNP) produced per $\mathrm{ml}$ per min under assay condition. The percentage of cutinase 


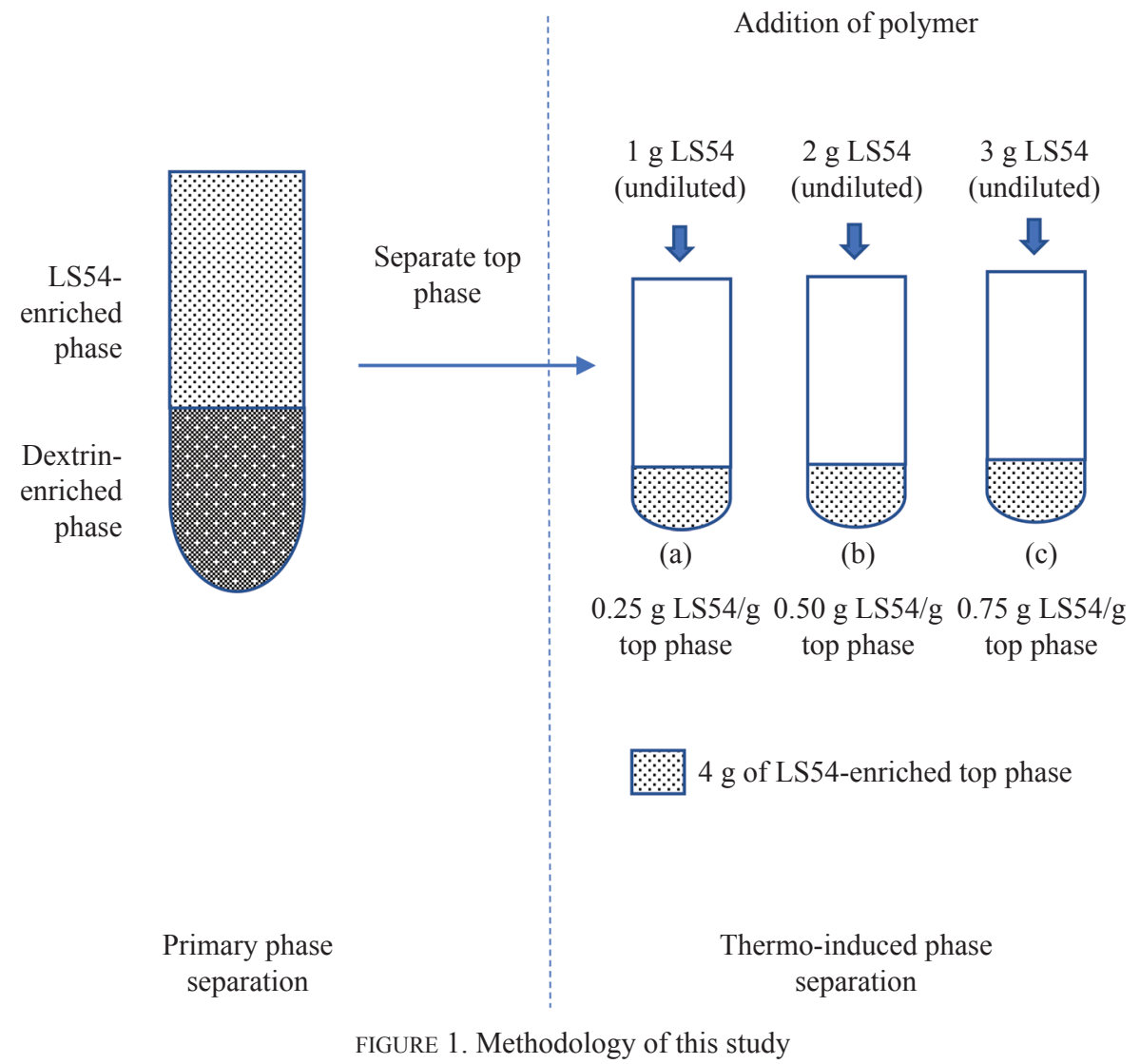

recovery in top phase (for primary phase separation) was calculated according to equation (1):

$$
\mathrm{Y}(\%)=\frac{\mathrm{C}_{\mathrm{t}} \mathrm{V}_{\mathrm{t}}}{\mathrm{C}_{\mathrm{t}} \mathrm{V}_{\mathrm{t}}+\mathrm{C}_{\mathrm{b}} \mathrm{V}_{\mathrm{b}}} \times 100=\frac{100}{1+\left(\frac{1}{\mathrm{k}_{\text {cut }} \cdot \mathrm{V}_{\mathrm{R}}}\right)}
$$

where $\mathrm{C}_{\mathrm{t}}$ and $\mathrm{C}_{\mathrm{b}}$ represent cutinase activity in top and bottom phase, respectively.

Meanwhile, the yield of cutinase in water-enriched bottom phase, after the thermo-induced separation was determined as below:

$$
\begin{aligned}
\text { Yield }_{\text {thermo }}(\%) & =\frac{\text { To cut act in the water phase }}{\text { To cut act in LS54-enriched phase }} \times 100 \\
& =(C w \cdot V w / C t \cdot V t) \times 100
\end{aligned}
$$

Where, $C w$ and $C t$ were cutinase activity in waterenriched phase and LS54-enriched top phase (of primary phase separation), respectively. Whereas $V w$ was the volume of water-enriched phase and $V t$ was the volume of LS54-enriched top phase (of primary phase separation). Furthermore, as a measure of the concentrating effect of the cutinase enzyme in the water phase, the concentrating factor, $c f$ was also calculated according to Equation (3):

$$
c f=\frac{\mathrm{v}_{\mathrm{T}}+\mathrm{v}_{\mathrm{B}}}{\mathrm{v}_{\mathrm{B}}}
$$

where $\mathrm{v}_{\mathrm{T}}$ and $\mathrm{v}_{\mathrm{B}}$ : volume of top phase and bottom phase, respectively.

\section{RESULTS AND DISCUSSION}

Initially, extraction of cutinase was carried out using LS54/ Dx system under condition of 22\% LS54/ 12.5\% Dx/ 0.1M $\mathrm{Na}_{2} \mathrm{SO}_{4}$ and $\mathrm{pH}: 8.0$. This condition was selected as it is the optimum condition for cutinase initial phase separation that obtained in a previous study (Jahim et al. 2012). After primary phase separation, approximately $79.4 \%$ of cutinase enzyme was successfully recovered in Dehypon ${ }^{\circledR L S} 54$ (LS54)-enriched top phase. Then, the enzyme extraction was continued with thermo-induced phase separation. At this stage, a new two-phase system consisting of top polymerenriched phase and bottom water-enriched phase was formed by increasing the LS54-enriched phase temperature up to $35^{\circ} \mathrm{C}$ in water bath. Ratio top phase to bottom phase volume obtained was 3.4.

After thermoseparation step, approximately $70 \%$ of cutinase enzyme in the LS54-enriched top phase (from the primary phase separation) was recovered in water-enriched bottom phase. Hence, due to increase cutinase recovery in the water phase, more polymer (LS54) was added in order to enhance volume excluded effect in the extraction system. According to Ducheyne et al. (2011), as the concentration increases, the swelling of the chain is counteracted by the presence of other chains; thus, leading to a screening effect of the volume excluded interactions between monomers belonging to the same chain. As a result, the polymer chains will pack tightly, which leads to an osmotic penalty; since the protein, volume becomes inaccessible to the polymer 
monomers (Ducheyne et al. 2011). The same self-aggregation will continually occur if the concentration is increased to a certain degree at the same constant temperature. The volume- exclusion effect at high polymer concentration was illustrated in Figure 2.

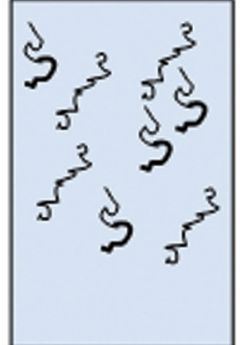

(a)

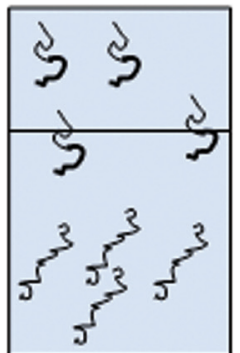

(b)

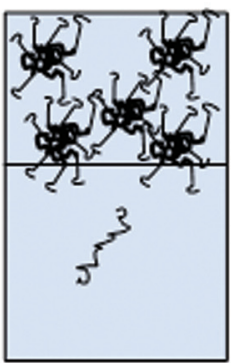

(c)

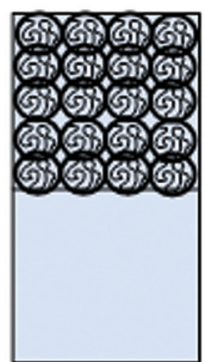

(d)

Hydrophobic chain

FIGURE 2. Illustration of volume excluded effect on phase separation of the aqueous polymer system. (a) polymer mixture;

(b) primary phase separation; (c) temperature-induced phase separation; (d) temperature-induced phase separation with polymer addition in the system

Furthermore, it was also found that the polymer (Dehypon ${ }^{\circledR L S 54}$ ) structure had a significant contribution to the accumulation of cutinase in the water phase. Dehypon ${ }^{\circledR}$ LS54 is a non-ionic surfactant that composed of fatty alcohol and two polymers blocks which are ethylene oxide $(E O)$ and propylene oxides $(P O)$ (Figure 3). Besides propylene oxide, fatty alcohol chain $(R)$ that located at the other end of the LS54 structure is also displayed as a hydrophobic character. According to Tani et al. (2001), polymer/surfactant that consists of hydrophobic character at both ends of its structure could perform higher extractability due to micellar network construction that enhances the excluded-volume interaction between the micelles/polymer and protein/enzyme (as shown in Figure 4).



Aliphatic group, $R$ Ethylene oxide, $E O$ Propylene oxide, $P O$

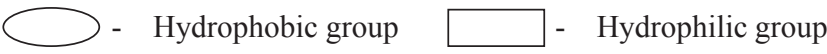

FIGURE 3. Molecule structure of Dehypon ${ }^{\circledR}$ LS54

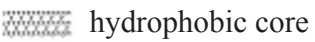

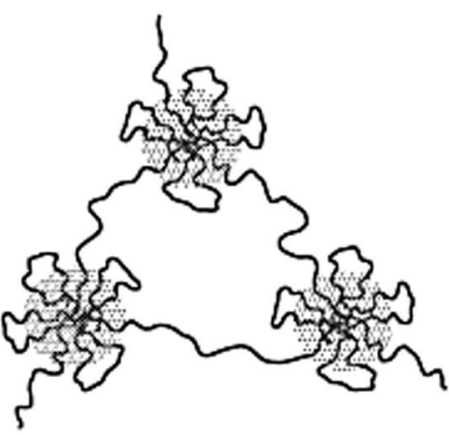

FIGURE 4. Construction of micelles network structures for a polymer with hydrophobic characters at both end (Tani et al. 2001)
Experimental result for cutinase enzyme recovery in thermoseparation phase was shown in Table 1. At this stage, the top phase of the system was consisted of polymer (LS54), while the bottom phase was enriched with water. As refer to Table 1, it was observed that addition of LS54 in thermo-induced phase had affected phase volume ratio, $v_{R}$ of the extraction system. The volume of water-enriched phase was decreased significantly with the addition of LS54. Apparently, the addition of the polymer had increased the volume of polymer phase. This initiated exclusion effect which had resulted in a rise of cutinase recovery in water enriched phase. The cutinase recovery had improved by up to $12 \%$ ( $82 \%$ recovery) when $0.5 \mathrm{~g} \mathrm{LS} 54 / \mathrm{g}$ top phase was added. However, enzyme recovery in water-enriched phase had a small increased (84\% recovery) with the further addition of polymer (which is a $0.75 \mathrm{~g} \mathrm{LS} 54 / \mathrm{g}$ top phase) in the system.

Meanwhile, a concentration factor of water phase for 0.5 $\mathrm{g}$ and $0.75 \mathrm{~g} \mathrm{LS} 54 / \mathrm{g}$ top phase were 5.5 and 5.8 respectively. The small increment of enzyme recovery in water phase and concentration factor $(c f)$ between the two values of polymer addition $(0.5 \mathrm{~g}$ and $0.75 \mathrm{~g} / \mathrm{g}$ top phase) explained that the addition of $0.5 \mathrm{~g} \mathrm{LS54/g}$ top phase was sufficient to optimize the cutinase recovery in water-enriched phase since more polymer addition, gave a small increment to the enzyme recovery. Furthermore, a system with lower polymer concentration is less viscous. Thus it would be easier to handle compared to a system with $0.75 \mathrm{~g}$ LS54/g top phase.

As compared to other strategies, the yield value achieved in this study was slightly lower (Table 2). However, it was expected since other methods were specific in action, and more works were needed to be done. Yet, the polymer addition was managed to increase the cutinase recovery in water phase after thermos-induced step. Besides simple in term of technique, it was also an advantage to be able to recover the enzyme in water-enriched phase. 
TABLE 1. Recovery of cutinase in thermo-induced separation step with and without additional polymer (LS54)

\begin{tabular}{|c|c|c|c|c|c|c|}
\hline Extraction system & $\begin{array}{c}\text { Top phase } \\
(\mathrm{g})\end{array}$ & $\begin{array}{c}\text { Bottom phase } \\
\text { (g) }\end{array}$ & $\begin{array}{c}\text { Phase volume ratio, } \\
v_{R}\end{array}$ & $\begin{array}{l}\text { Total enzyme act. } \\
(\mathrm{U} / \mathrm{ml})\end{array}$ & $\begin{array}{c}\text { Total recovery } \\
(\%)\end{array}$ & $c f$ \\
\hline Primary recovery & 4.0 & - & - & 2.6 & - & - \\
\hline \multicolumn{7}{|c|}{ Thermo-induced phase separation: } \\
\hline Without additional LS54 & 3.09 & 0.91 & 3.4 & 1.82 & 70.0 & 4.4 \\
\hline \multicolumn{7}{|l|}{ Addition of LS54: } \\
\hline $0.25 \mathrm{~g} \mathrm{LS} 54 / \mathrm{g} \mathrm{tp}$ & 4.08 & 0.92 & 4.0 & 1.95 & 75.0 & 5.0 \\
\hline $0.50 \mathrm{~g} \mathrm{LS} 54 / \mathrm{g}$ tp & 4.9 & 1.1 & 4.5 & 2.13 & 81.9 & 5.5 \\
\hline $0.75 \mathrm{~g} \mathrm{LS} 54 / \mathrm{g}$ tp & 5.8 & 1.2 & 4.8 & 2.17 & 83.5 & 5.8 \\
\hline
\end{tabular}

${ }^{*} t p=$ top phase of primary phase separation

TABLE 2. Comparison of ATPS studies with different strategies to increase yield value

\begin{tabular}{|c|c|c|c|c|}
\hline System & Target biomolecule & Strategy & $\begin{array}{l}\text { Performance } \\
\text { parameter }\end{array}$ & Ref \\
\hline UCON/dextran & $\operatorname{IgG}$ & $\begin{array}{l}\text { Add free ligand into system (trietilena } \\
\text { glycol-asid diglutarik (TEG-COOH) }\end{array}$ & $\begin{array}{l}\text { - } \mathrm{Y}=85 \% \\
\text { - Purity }=88 \%\end{array}$ & $\begin{array}{l}\text { (Ferreira et al. } \\
\text { 2008) }\end{array}$ \\
\hline PEG/dextran & $\operatorname{IgG}$ & $\begin{array}{l}\text { Attach ligand to a system component } \\
\text { (PEG-asid diglutarik) }\end{array}$ & - $\mathrm{Y}=93 \%$ & (Rosa et al. 2007) \\
\hline $\begin{array}{l}\mathrm{C}_{10} \mathrm{G}_{1} \text { micellar aqueous } \\
\text { two phase system }\end{array}$ & $\begin{array}{l}\text { Green flouroscent } \\
\text { protein, GFP }\end{array}$ & $\begin{array}{l}\text { Attach affinity tag (CBM9) to the target } \\
\text { protein (GFP-CBM9) }\end{array}$ & - $k=3.3$ & $\begin{array}{l}\text { (Mazzola et al. } \\
\text { 2006) }\end{array}$ \\
\hline PEG1000/fosfat & ribonucleose & $\begin{array}{l}\text { PEGylation (covalently attached PEG to } \\
\text { protein atau drug molecules) }\end{array}$ & - $\mathrm{Y}=>90 \%$ & $\begin{array}{l}\text { (González-Valdez } \\
\text { et al. 2012) }\end{array}$ \\
\hline $\mathrm{PEG} 300 / \mathrm{Na}_{2} \mathrm{SO}_{4}$ & Gallic acid & $\begin{array}{l}\text { Addition of ionic liquid } \\
\text { a. }\left[\mathrm{C}_{4} \text { mpip }\right] \mathrm{TOS} \\
\text { b. }\left[\mathrm{C}_{4} \mathrm{mpip}\right] \mathrm{SCN} \\
\text { c. }\left[\mathrm{C}_{4} \mathrm{mpip}\right](\mathrm{N}) \mathrm{CN}_{2} \\
\text { d. }\left[\mathrm{C}_{4} \mathrm{mpip}\right] \mathrm{CH}_{3} \mathrm{CO}_{2} \\
\text { e. }\left[\mathrm{C}_{4} \mathrm{mpip}\right] \mathrm{Cl}\end{array}$ & $\begin{array}{l}\text { - } k=2.3-29.0 \\
\text { - } \mathrm{Y}=78-98 \%\end{array}$ & $\begin{array}{l}\text { (Almeida et al. } \\
\text { 2014) }\end{array}$ \\
\hline $\mathrm{PEG} / \mathrm{K}_{2} \mathrm{HPO}_{4}$ & RNA & Addition of neutral salt $(\mathrm{NaCl})$ & - $k=3.5$ & $\begin{array}{l}\text { (Luechau et al. } \\
\text { 2009) }\end{array}$ \\
\hline LS54/dextrin & Cutinase & $\begin{array}{l}\text { Addition of more polymers in extraction } \\
\text { system at thermo-induced step. }\end{array}$ & - $\mathrm{Y}=82 \%$ & This study \\
\hline
\end{tabular}

CONCLUSION

Cutinase recovery in water-enriched phase had been optimized by adding more polymer into LS54-enriched top phase (which is separated from primary phase separation). The optimum concentration obtained for polymer addition was $0.5 \mathrm{~g} \mathrm{LS} 54 / \mathrm{g}$ top phase. At this concentration, cutinase recovery in water-enriched phase had been increased to $82 \%$. The cutinase recovery in water-enriched phase showed an insignificant increase (84\%) with further addition of polymer ( $0.75 \mathrm{~g} \mathrm{LS} 54 / \mathrm{g}$ top phase) in the extraction system. It can be concluded that this optimization step is not only able to offer benefit for further enzyme purification stage because the target enzyme accumulated in water-enriched phase, but it also offers minimal use of additives in extraction system since the added polymer was the system component itself.

\section{ACKNOWLEDGEMENT}

The authors acknowledge the Ministry of Science, Technology and Innovation of Malaysia (MOSTI) and Universiti Kebangsaan Malaysia (UKM) for funding this research under grant UKM-AP-BPB-12-2009.

\section{REFERENCES}

Almeida, M. R., Passos, H., Pereira, M. M., Lima, Á. S., Coutinho, J. A. P. \& Freire, M. G. 2014. Ionic liquids as additives to enhance the extraction of antioxidants in aqueous two-phase systems. Separation and Purification Technology 128(0): 1-10.

Asenjo, J. A. \& Andrews, B. A. 2012. Aqueous two-phase systems for protein separation: Phase separation and applications. Journal of Chromatography A 1238 (2012):1-10. 
Ducheyne, P., Healy, K., Hutmacher, D. E., Grainger, D. W. \& Kirkpatrick, C. J. 2011. Comprehensive Biomaterials: Online Version. Elsevier Science.

Espitia-Saloma, E., Vázquez-Villegas, P., Aguilar, O. \& RitoPalomares, M. 2014. Continuous aqueous two-phase systems devices for the recovery of biological products. Food and Bioproducts Processing 92(2): 101-112.

Ferreira, I. F., Azevedo, A. M., Rosa, P. A. J. \& Aires-Barros, M. R. 2008. Purification of human immunoglobulin G by thermoseparating aqueous two-phase systems. Journal of Chromatography A 1195(1-2): 94-100.

Goja, A. M., Hong, Y., Min, C. \& Charles, L. 2013. Aqueous Two Phase Extraction For Bioseparation. Bioprocessing and Biotechniques 4(1): 1-8.

González-Valdez, J., Rito-Palomares, M. \& Benavides, J. 2012. Advances and trends in the design, analysis, and characterization of polymer-protein conjugates for "PEGylaided" bioprocesses. Analytical and Bioanalytical Chemistry 403(8): 2225-2235.

Jahim, J. M., Mohammad, A. W., Mutalib, F. A. A., Bakar, F. D. A. \& Hassan, O. 2012. Optimisation of LS54/Dx Aqueous Two Phase System Conditions for Cutinase Recovery. ASEAN Journal of Chemical Engineering 12(2): 61-69.

Johansson, H. O., Karlström, G., Tjerneld, F. \& Haynes, C. A. 1998. Driving forces for phase separation and partitioning in aqueous two-phase systems. Journal of Chromatography. B, Biomedical Sciences and Applications 711(1-2): 3-17.

Jonsson, M. \& Johansson, H. 2003. Protein partitioning in thermoseparating systems of a charged hydrophobically modified ethylene oxide polymer. Journal of Chromatography A 983: 133-144.

Kumar, S., Kikon, K., Upadhyay, A., Kanwar, S. S. \& Gupta, R. 2005. Production, purification, and characterization of lipase from thermophilic and alkaliphilic Bacillus coagulans BTS-3. Protein Expression and Purification 41(1): 38-44.

Luechau, F., Ling, T. C. \& Lyddiatt, A. 2009. Selective partition of plasmid DNA and RNA in aqueous twophase systems by the addition of neutral salt. Separation and Purification Technology 68(1): 114-118.

Mazzola, P. G., Lam, H., Kavoosi, M., Haynes, C. A., Pessoa, A., Penna, T. C. V. \& Blankschtein, D. 2006. Affinitytagged green fluorescent protein (GFP) extraction from a clarified E. coli cell lysate using a two-phase aqueous micellar system. Biotechnology and Bioengineering 93(5): 998-1004.

Rosa, P. A. J., Azevedo, A. M., Ferreira, I. F., Vries, J. d., Korporal, R., Verhoef, H. J. \& Aires-Barros, M. R. 2007. Affinity Partitioning of Human Antibodes in Aqueous Two-Phase Systems. Journal of Chromatography A 1162(1): 103-113.

Rosa, P. A. J., Ferreira, I. F., Azevedo, A. M. \& AiresBarros, M. R. 2010. Review: Aqueous two-phase systems: A viable platform in the manufacturing of biopharmaceuticals. Journal of Chromatography A 1217(16):2267-2746.
Tani, H., Suzuki, Y., Matsuda, A. \& Kamidate, T. 2001 Enhancement of the excluded-volume effect in protein extraction using triblock copolymer-based aqueous micellar two-phase systems. Science 429: 301-309.

Van, R. D., Lazzara, M. J., Van den Broeke, L. J. P., Keurentjes, J. T. F. \& Blankschtein, D. 2004. Protein partitioning driven by excluded-volume interactions in an aqueous nonionic micellar-gel system. Biotechnology and Bioengineering 87(6): 695-703.

Fariza Akmal Abdul Mutalib

Department of Chemical and Process Engineering Faculty of Engineering \& Built Environment Universiti Kebangsaan Malaysia (UKM)

43600, Bangi, Selangor, Malaysia.

*Jamaliah Md Jahim

Department of Chemical and Process Engineering

Faculty of Engineering \& Built Environment

Universiti Kebangsaan Malaysia (UKM)

43600, Bangi, Selangor, Malaysia.

Research Centre for Sustainable Process Technology

Faculty of Engineering \& Built Environment

Universiti Kebangsaan Malaysia (UKM)

43600, Bangi, Selangor, Malaysia.

Abdul Wahab Mohammad

Department of Chemical and Process Engineering

Faculty of Engineering \& Built Environment

Universiti Kebangsaan Malaysia (UKM)

43600, Bangi, Selangor, Malaysia.

Research Centre for Sustainable Process Technology

Faculty of Engineering \& Built Environment

Universiti Kebangsaan Malaysia (UKM)

43600, Bangi, Selangor, Malaysia.

Qatar Energy and Environment Research Instititue

Hamad bin Khalifa University (HBKU)

Qatar Foundation, Doha, Qatar.

Farah Diba Abu Bakar

Centre of Bioscience \& Biotechnology Studies

Faculty of Science \& Technology

Universiti Kebangsaan Malaysia (UKM)

43600, Bangi, Selangor, Malaysia.

*Corresponding author; email: jamal@ukm.edu.my

Received date: $20^{\text {th }}$ January 2018

Accepted date: $6^{\text {th }}$ August 2018

Online First date: $1^{\text {st }}$ September 2018

Published date: $31^{\text {st }}$ October 2018 